\title{
E-Learning Usage Outcomes among University Learners: A Pilot Study
}

\section{A. Devisakti ${ }^{\circledR}(\mathbb{1})$ \\ T. Ramayah ${ }^{2}$}

'Universiti Sains Malaysia, Malaysia.

Email:dda15_man026@student.usm.mvTel:0143040536

'School of Management, Universiti Sains Malaysia, Malaysia.

Email:ramayah@usm.my Tel:604-6539889

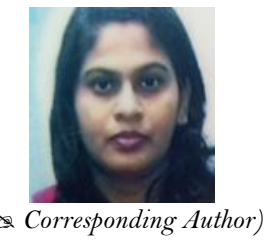

( Corresponding Author

\section{Abstract}

E-learning has the potential to attract learners into the learning environment with its abundance of benefits. However, learners tend to discontinue the usage of the e-learning portal if their performance in the study is not encouraging. Therefore, the aim of this research is to discuss on pilot test process on a proposed new model before commencing the main research e-learning. A pilot study was conducted to assess the usability and reliability of the survey questionnaire. An online survey method was used to collect 108 data from higher education institutions (HEIs) in Malaysia. The results agreed that most of the constructs in the proposed model have Cronbach alpha ranges from 0.801 to 0.906 which indicates the constructs have good reliability. Therefore, the constructs in the questionnaire are acceptable for future research on a bigger scale. The result provides useful information to the e-learning portal adopted by HEIs on factors that could affect usage and further outcome of the e-learning portal. In order to contribute to the body of research in this context, the researcher describes the pilot test process and methodology before commencing with the main study. A new proposed model was used which integrates TPB theory, IS Success Model together with Attachment which may provide a more comprehensive model for examining e-learning usage outcomes. Most other similar studies mostly conducted on undergraduates but this study intends to focus on postgraduates in both public and private HEIs.

Keywords: Pilot study, E-learning, Outcomes, Usage, Learners, Higher education institutions.

Citation | A Devisakti (2019) E-Learning Usage Outcomes among University Learners: A Pilot Study. Journal of Education and eLearning Research, 6(3): 149-155.

History:

Received: 12 April 2019

Revised: 9 May 2019

Accepted: 17 June 2019

Published: 3 September 2019

Licensed: This work is licensed under a Creative Commons Attribution 3.0 License (cc)

Publisher: Asian Online Journal Publishing Group
Acknowledgement: Both authors contributed equally to the conception and design of the study. Appreciation is extended to the MoHE for MyBrain design of the study. Appreciation is extended to the MoHE for $\mathrm{MyB}$
scholarship to support student engagement in PhD study and research. Funding: This study received no specific financial support.

Competing Interests: The authors declare that they have no conflict of interests.

Transparency: The authors confirm that the manuscript is an honest, accurate, and transparent account of the study was reported; that no vital features of the study have been omitted; and that any discrepancies from the features of the study have been omits
study as planned have been explained.

study as planned have been explained.
Ethical: This study follows all ethical practices during writing.

\section{Contents}

1. Introduction

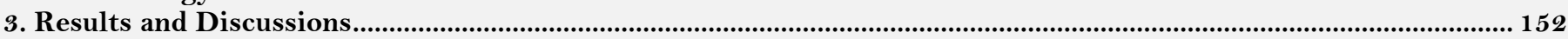

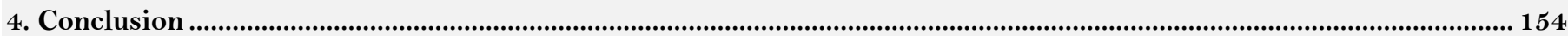

References 


\section{Contribution of this paper to the literature}

This study contributes to the existing literature by providing a new framework for e-learning usage and outcomes by integrating attachment theory into TPB and IS Success Model. This study also highlights the need for a pilot study in term of improved research design and adds to the body of knowledge of pilot study in the e-learning context.

\section{Introduction}

The advancement of information and communication technologies (ICT), in parallel with the increased demand for improved access to higher education, has given way for rapid e-learning adoption (Oh and Yoon, 2014). Higher education institutions (HEIs) are presently utilizing their information technology to enhance their teaching in form of e-learning. E-learning system is becoming crucial technologies as higher education institutions are competing in order to reduce cost attract more learners to meet their educational needs (Arpaci, 2015). Thus, many higher learning institutions lavishly investing in their information systems (Mouakket and Bettayeb, 2015).

E-learning has turned into an alternative method to traditional face-to-face education and teaching is no longer restricted to classrooms. The modern technology especially the Internet has transformed education that was once limited within four walls. This shift from traditional method to use of technology mediated tools is referred to as electronic learning (e-learning) (Yakubu and Dasuki, 2018). E-learning technologies have given education field a paradigm shift from teacher-centered to learner-centered (Oye et al., 2014). Past studies demonstrated that anywhere and anytime learning and access to information and communication are facilitated through e-learning (Peña-Ayala et al., 2014; Nurakun et al., 2018; Yakubu and Dasuki, 2018).

Furthermore, e-learning has emerged as the new paradigm in the field of education especially in this new millennium. The overall teaching/learning processes in the learning environment were redefined through elearning. According to e-learning markets trends and forecast 2014-2016 report, the estimated revenues should reach $\$ 51.4$ billion by 2016 (Pappas, 2015). The report further elaborates that the highest growth rate is in Asia at $17.3 \%$, followed by other regions. This has spurred on a robust and unstoppable surge in income for e-learning initiatives, which is expected to reach US\$168.8 billion by 2018 (Pappas, 2015).

\subsection{Purpose of the Pilot Study}

The pilot study refers to a study conducted before the main research and closely related to a larger study (Eldridge et al., 2016). A pilot study is a study done on a smaller scale or trial to assure that the real study will be carried out successfully. According to Yin (1989) a pilot study will assist investigators to fully refine the plans of data collected based on the data content as well as the relevant procedures. Testing the questionnaire is the main aim of a pilot study. According to Teijlingen and Hundley (2002) objectives of conducting a pilot study are (a) testing adequacy of research instruments (b) assessment of the feasibility of a full-scale project (c) assessing whether the research protocol is realistic and workable (d) revealing reveal logistic issues (e) collecting preliminary data (f) ensuring whether the sampling frame and technique are effective (g) determining sample size (h) convincing funding bodies that the major study is feasible and worth funding. There is strong support in past literature that a pilot study should be undertaken in order to identify future risks related to sample size, data collection method, sample selection, data management and data analysis (Moore et al., 2011).

In addition, most of the pilot study published came from medicine field (Lancaster, 2015) and much lacking in other fields (Teijlingen and Hundley, 2002). In addition, Eldridge et al. (2016) suggested that more pilot study need to be published for sharing information.

This pilot study was carried out in order to fulfill the following objectives:

- To prepare a questionnaire by conveying the three main areas: factors influencing e-learning portal use, elearning portal usage, performance and grit.

- To analyse the reliability and validity of the questions.

The pilot study also intends to answer the following research objective:

- Does the designed questionnaire address the objectives?

\section{Methodology}

Based on the previous researches reviewed, a framework is proposed as depicted in Figure 1. This study is based on the integration of Theory of Planned Behaviour (TPB), IS Success Model and Attachment Theory into a new model. The TPB theory was coined by Ajzen (1985) with the objective of predicting and explaining individual behaviour in different circumstances. The TPB postulates a set of relationship between attitude, subjective norms, perceived behavioural control, behavioural intentions, and behaviour. IS Success Model was developed by DeLone and McLean in 1992 in order to measure IS-impact. Theory of Attachment was postulated by Bowlby (1960). This theory explains how individuals form and maintain attachment to others. At the early stage, the attachment was referring to the attachment between infants and their parents. At the early stage, the attachment was referring to the attachment between infants and their parents. However, in the flow of time, different kinds of attachment have been conceptualized in different contexts (Wu et al., 2017). This new model is an integration of IS model together with other psychology models which provides a more comprehensive model in examining e-learning usage outcomes. The model below consists of seven independent variables (attitude, instructor influence, peer influence, self-efficacy, emotional attachment, sense of belonging) that may have an impact on e-learning portal usage. Further, e-learning usage may influence performance of learners. Performance is the outcome of the proposed model. Grit is added to the below mentioned model as moderator. Grit is proposed to moderate the relationship between learner's attitude and e-learning portal usage. Therefore, there are 10 constructs in the proposed model below. 


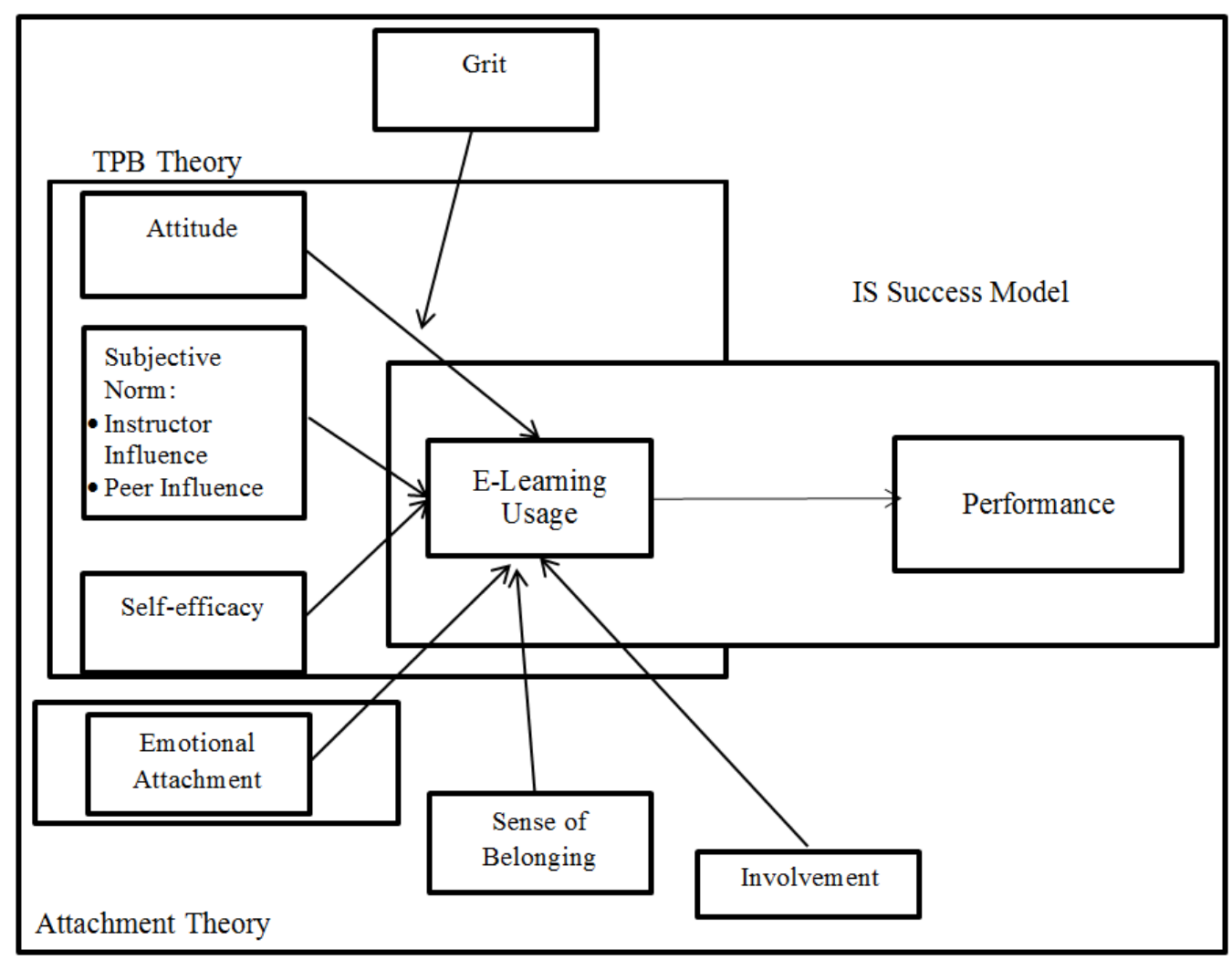

Figure-1. Research framework.

Source: Ajzen (2011); DeLone and McLean (1992); Duckworth and Quinn (2009); Fredrickson (2015); Asatryan et al. (2013); Read et al. (2011).

In this pilot study, the sampling of respondents is based on purposive sampling. The purposive sampling method was chosen as the selection of respondents are those who are in the best position to provide the data needed (Sekaran and Roger, 2016). The sample consists of e-learning users from both public and private universities. Therefore, the samples for the pilot study were collected from one public and one private university in Penang. The respondents were postgraduate students from both types of institutions. Respondents were selected based on the following criteria: (1) Respondents must be pursuing postgraduate study either in public or private university (coursework) and (2) respondents must be using e-learning currently (more than six months).

A pre-test was conducted before proceed with the pilot test. Pre-test is a step where a group of experts and respondents are required to answer the questionnaire in order to iron out issues in the instruments or design of the questionnaire (Zikmund et al., 2012). The purpose of pre-test the questionnaire is to ensure that the questionnaire items are well understood by the respondents. Furthermore, this might help researcher in rectifying any inadequacies before administering the final version of the questionnaire to the target respondents and thus reducing biases (Sekaran and Roger, 2016). Pre-test on the data collection instrument with three subject matter experts and three learners were recruited to identify the problem with the data collection instruments. The content validity of the instrument was reviewed by a panel of experts in the field of education and language. The content validity of the questionnaire used in this study were evaluated by panel members earned PhD in the field of education and language. All panel members are employed full time at university at the time of review. Panel members were required to evaluate items and the instruments as a whole through electronic mail. These experts gave their views and suggestions with regards the content of each of the dimensions included in the questionnaire. Besides that, time taken to complete the draft questionnaire by students was being timed by researcher. Lastly, changes were made to the questionnaire based on their feedback. The pre-test lead to some modifications in the questionnaire. Items were revised in accordance with the results from pre-test to improve face and content validity as well as reliability.

All the construct were adapted and adopted from past literature. Section A: had seven subsections that cover factors that influence e-learning portal usage. While section B: had two subsections that cover areas of e-learning portal usage and performance. Section $\mathrm{C}$ comprised of six questions related to grit and the last section comprised of nine questions related to demographic information of respondents. The pilot study used a closed ended question in the questionnaire. In a closed ended questionnaire, respondents will give choices among a set of alternatives given by the researcher. All items in a questionnaire using a nominal, ordinal Likert or ratio scale are considered closed ended questions (Sekaran and Roger, 2016). Closed ended questions help the respondents to make quick decisions to choose among the several alternatives before them. They also help the researcher to code the information easily for subsequent analysis. Any questions that lead it to different possible responses is called the double-barrelled question. Such questions will be avoided or eliminated. Even ambiguous (respondent may not be sure of what it means) questions should be avoided as it may lead to an incorrect answer.

The items used in section A and C used a seven-point Likert scale, where respondents indicated their extent of agreement with a statement from a scale of 1-7 ( $1=$ strongly disagree and $7=$ strongly agree), while involvement construct uses the scale from 1 to 7 ( $1=$ not at all and $7=$ very high extent). Items in section B will a five-point Likert scale, where respondents indicate their extent of agreement with the statement from a scale of 1-5 ( $1=$ strongly disagree and $5=$ strongly agree). The items for each of the constructs are as in Table 2. Five issues were considered when designing the questionnaire for the pilot study: (i) the appropriateness of the content of the questions, (ii) how the questions are worded and the level of sophistication of the language used, (iii) the type and form of questions asked, (iv) the sequencing of the questions, (v) the personal data sought from the respondents. The present study also tried to apply the suggestion by Sekaran and Roger (2016) and Oppenheim (1992) to keep statements/ questions short, simple, and not more than 20 words per sentence. Keeping to the above mentioned 
rule of thumb, the present study's questionnaire items less than 20 words. Furthermore, Sekaran and Roger (2016) suggested that the language and wording used in the questionnaire should be appropriate to the respondents' level of understanding.

The pilot test was conducted over a period of two weeks. First, emails attached with an online link (Google form) was sent to lecturers (instructors) in both universities in order to circulate the survey to their learners in their e-learning platform. The online survey will be attached with a cover letter includes details on the purpose of the study, eligibility of the respondents, and confidentiality assurance on their responses as well as directions on answering the survey questions. Besides that, emails were also sent to the postgraduate associations in HEIs to be circulated to their registered postgraduate students. In addition, the researcher also opted to use social media in order to distribute the online survey. An online link was also posted on social media belong to the two universities including Facebook, Twitter, Telegram and Whatsapp groups with the consent of the moderator. Furthermore, the online link was posted on social media belongs to the postgraduate associations of public and private HEIs. In addition, the same online link was also sent through a private message to individual respondents who are the member of the two university social media groups. After 3 days, a follow-up e-mail or message will be after first email or message, and later a second and third follow-up after an additional week. By clicking on the link participants will be informed that their participation is voluntary and that it would take approximately eight to ten minutes to complete the questionnaire. Researcher tested the process of distributing the questionnaire to evaluate appropriate email or message was sent and received, the online survey is easily accessed and completed in time. The online survey yielded 133 responses and 5 questionnaires were discarded as it was incomplete or did not fulfill the preliminary requirements. Hence, potentially 108 responses were used for further analysis.

\section{Results and Discussions}

The 108 data were analyzed using SPSS software (Statistic Package for the Social Sciences). Frequency test was used to analyse the information provided by the respondents. Most of the participants were mainly female $(56.5 \%)$ while male $(43.5 \%)$. Most of the respondents were in the age group of 30-39 years $(49.1 \%)$ followed by below 29 years (37\%), 40-49 years ( $13 \%)$ and above 50 years $(0.9 \%) .48 \%$ of the respondents were Chinese, followed by Malay (32.4\%), Indian (13\%) and others (6.5\%). 60.2\% of the respondents were from the public university while $39.8 \%$ of respondents were from the private university. Most of the respondents have 1-3 years $(60.2 \%)$ of e-learning portal use experience, followed by less than 1 year $(23.1 \%)$ and the others have either 4-6 years $(6.5 \%)$, more than 9 years $(5.6 \%)$ and $7-9$ years' experience $(4.6 \%)$.

Table-1. Respondents demographic profile.

\begin{tabular}{|c|c|c|c|}
\hline Variable & Category & Frequency & Percentage \\
\hline \multirow[t]{2}{*}{ Gender } & Male & 47 & 43.5 \\
\hline & Female & 61 & 56.5 \\
\hline \multirow[t]{4}{*}{ Age } & 29 years and below & 40 & 37 \\
\hline & 30-39 years & 53 & 49.1 \\
\hline & $40-49$ years & 14 & 13 \\
\hline & 50 and above & 1 & 0.9 \\
\hline \multirow[t]{4}{*}{ Race } & Malay & 35 & 32.4 \\
\hline & Chinese & 52 & 48 \\
\hline & Indian & 14 & 13 \\
\hline & Others & 7 & 6.5 \\
\hline \multirow{2}{*}{ Pursuing postgraduate studies in a } & Public university & 65 & 60.2 \\
\hline & Private university & 43 & 39.8 \\
\hline \multirow{5}{*}{ E-learning experience (months/years) } & Less than 1 year & 25 & 23.1 \\
\hline & $1-3$ years & 65 & 60.2 \\
\hline & 4-6 years & 7 & 6.5 \\
\hline & $7-9$ years & 5 & 4.6 \\
\hline & More than 9 years & 6 & 5.6 \\
\hline \multirow{5}{*}{ Internet and computer experience (months/years) } & Less than 5 years & 6 & 5.5 \\
\hline & $6-10$ years & 30 & 27.8 \\
\hline & $11-15$ years & 24 & 22.2 \\
\hline & 16-20 years & 33 & 30.6 \\
\hline & More than 20 years & 15 & 13.9 \\
\hline \multirow{5}{*}{ Frequency of e-learning portal use (hours per week) } & Less than 1 hour & 5 & 4.9 \\
\hline & $1-5$ hours & 63 & 58.3 \\
\hline & 6-10 hours & 24 & 22.2 \\
\hline & 11-15 hours & 8 & 7.3 \\
\hline & More than 15 hours & 8 & 7.3 \\
\hline \multirow{5}{*}{ Type of e-learning portal used } & Moodle & 14 & 13 \\
\hline & Blackboard & 51 & 47.2 \\
\hline & Open source (MOOC) & 2 & 1.9 \\
\hline & Edmodo & 10 & 9.3 \\
\hline & University portal & 31 & 28.7 \\
\hline \multirow{4}{*}{ Current CGPA } & 2.99 and below & 3 & 2.8 \\
\hline & $3.0-3.49$ & 52 & 48.1 \\
\hline & 3.5 and above & 50 & 46.3 \\
\hline & Not sure / confidential & 3 & 2.8 \\
\hline
\end{tabular}

Many respondents have internet and computer experience of $16-20$ years $(30.6 \%)$ while others have $6-10$ years (27.8\%), 11-15 years $(22.2 \%)$, more than 20 years $(13.9 \%)$ and less 5 years $(5.5 \%)$. Blackboard was the popular e- 
learning platform used by almost (47.2\%). Meanwhile, $9.3 \%$ of students use Edmodo, $1.9 \%$ use open source (MOOC) and $13 \%$ use Moodle. Around 25\% of students only mentioned that they are using their university system. Most of the students gained CGPA of 3.0-3.5 (48.1\%). Followed by CGPA above 3.5(46.3\%) and less than $3.0(2.8 \%) .2 .8 \%$ of students either not sure of their CGPA or not willing to reveal.

The online survey (Google form) was deemed to be appropriate to collect data from e-learning users in higher education institutions. The response of participants to the reminder emails or messages indicated that it is crucial in following the same step in larger data collection procedure later. The online survey indicated that all the questions could be completed in approximately eight to ten minutes. Therefore, it is assumed that the time to complete would be sufficient to garner a response from participants. The unanswered questions were avoided as participants were not allowed to go to the next questions without answering in the online survey. This further could avoid missing data in the main study later.

Table-2. Measurement items.

\begin{tabular}{|c|c|}
\hline Construct & Items \\
\hline \multirow{3}{*}{$\begin{array}{l}\text { Attitude } \\
\text { (Alharbi and Drew, } \\
2014 \text { ) }\end{array}$} & I believe it is a good idea to use e-learning portal for my study. \\
\hline & I like the idea of using e-learning portal for my study. \\
\hline & I am positive towards using e-learning portal for my study. \\
\hline \multirow{3}{*}{$\begin{array}{l}\text { Instructor influence } \\
\text { (Teo and Van } \\
\text { Schaik, 2012) }\end{array}$} & My lecturer/tutor thinks it is important for me to use e-learning portal for my study. \\
\hline & My lecturer/tutor wants me to use e-learning portal for my study. \\
\hline & My lecturer/tutor supports the use of e-learning portal for my study. \\
\hline \multirow{3}{*}{$\begin{array}{l}\text { Peer influence }(\mathrm{Wu} \\
\text { and Zhang, 2014) }\end{array}$} & My peers' beliefs about e-learning portal encourage me to use it. \\
\hline & $\begin{array}{l}\text { My peers thoughts about e-learning portal influence the degree to which } \\
\text { I use e-learning portal. }\end{array}$ \\
\hline & My peers' beliefs about the e-learning portal condition me to use it. \\
\hline \multirow{4}{*}{$\begin{array}{l}\text { Self-efficacy (Teo } \\
\text { and Van Schaik, } \\
\text { 2012) }\end{array}$} & I feel confident in using e-learning portal. \\
\hline & I can use the e-learning portal even if there is no one to teach me. \\
\hline & I can use the e-learning portal with minimal help. \\
\hline & I can overcome obstacles that occur when I use e-learning portal. \\
\hline \multirow{6}{*}{$\begin{array}{l}\text { Emotional } \\
\text { attachment (Read et } \\
\text { al., 2011) }\end{array}$} & I consider e-learning portal as a friend. \\
\hline & I love my e-learning portal. \\
\hline & E-learning portal makes me feel at peace. \\
\hline & I feel connected to the e-learning portal. \\
\hline & I feel bonded to the e-learning portal. \\
\hline & I am attached to the e-learning portal. \\
\hline \multirow{3}{*}{$\begin{array}{l}\text { Sense of belonging } \\
\text { (Asatryan et al., } \\
\text { 2013); (Lee and } \\
\text { Suh, 2015) }\end{array}$} & I feel I belong to the e-learning portal. \\
\hline & I feel "at home" (comfortable) in e-learning portal. \\
\hline & I don't feel like a stranger in the e-learning portal. \\
\hline \multirow{5}{*}{$\begin{array}{l}\text { Involvement } \\
\text { (Fredrickson, 2015) }\end{array}$} & I am involved in online chats, discussions via e-learning portal with lecturers/peers. \\
\hline & I am involved in online discussions forum. \\
\hline & I am involved in helping my peers via e-learning portal. \\
\hline & I post on online discussion forum regularly. \\
\hline & I use e-learning portal to get to know my course mates. \\
\hline \multirow{6}{*}{$\begin{array}{l}\text { Grit (Aparicio et al., } \\
2017 \text { ) }\end{array}$} & I finish whatever I begin. \\
\hline & Setbacks (delays and obstacles) don't discourage me. \\
\hline & I am hardworking. \\
\hline & I often set a goal and continue to pursue (follow) the same one. \\
\hline & $\begin{array}{l}\text { I can be obsessed with a certain idea or task for a short period but will not lose interest } \\
\text { in long run. }\end{array}$ \\
\hline & $\begin{array}{l}\text { I don't have difficulty maintaining my focus on tasks that takes more than few months } \\
\text { to complete. }\end{array}$ \\
\hline \multirow{4}{*}{$\begin{array}{l}\text { Usage (Lu et al., } \\
\text { 2009); } \\
\text { (Hsieh et al., 2016) }\end{array}$} & I use the e-learning portal a lot for my study. \\
\hline & I use the e-learning portal whenever possible for my study. \\
\hline & I use the e-learning portal frequently for my study. \\
\hline & I use the e-learning portal whenever appropriate for my study. \\
\hline \multirow{4}{*}{$\begin{array}{l}\text { Performance } \\
\text { (Mohammadyari } \\
\text { and Singh, 2015) }\end{array}$} & Using e-learning portal improves my performances in managing my study. \\
\hline & Using e-learning portal increases my productivity in managing my study. \\
\hline & Using e-learning portal enhances my effectiveness in managing my study. \\
\hline & Overall, e-learning portal is useful in managing my study. \\
\hline
\end{tabular}

Hair et al. (2010) defined reliability as an evaluation of the degree of consistency between variables. Reliability is a necessary condition to validity (Cooper and Schindler, 2003) therefore, the reliability of any instrument should be assessed first for appropriateness to assess validity (Hair et al., 2011). This study assesses the consistency of the entire scale with Cronbach's alpha. Cronbach's Alpha is the statistical method for testing constructs' reliability in research. The alpha value above 0.7 is the acceptable level in most of the studies (Cortina, 1993; Nurakun et al., 2018). Most of the constructs in this study have Cronbach alpha ranging from 0.801 to 0.906 see Table 3. All constructs have Cronbach's alpha values above 0.7, which means that all constructs have good internal consistency. Thus, refining the items to increase the reliability of the measures were not required. From this result of Cronbach's alpha coefficient value, this questionnaire was deemed acceptable. Table 3 below shows the mean, standard deviation and Cronbach alpha for all constructs. 


\begin{tabular}{l|c|c|c|c}
\multicolumn{5}{c}{ Table-3. Descriptive and reliability results. } \\
\hline Construct & Number of items & Mean & SD & Cronbach alpha \\
\hline Attitude & 3 & 6.015 & 0.843 & 0.900 \\
\hline Instructor influence & 3 & 5.688 & 1.053 & 0.887 \\
\hline Peer Influence & 3 & 4.926 & 1.307 & 0.890 \\
\hline Self-efficacy & 4 & 5.692 & 1.047 & 0.897 \\
\hline Sense of belonging & 3 & 4.612 & 1.457 & 0.876 \\
\hline Grit & 6 & 5.399 & 1.007 & 0.868 \\
\hline Emotional attachment & 6 & 4.472 & 1.457 & 0.906 \\
\hline Usage & 4 & 4.523 & 0.684 & 0.871 \\
\hline Performance & 4 & 4.062 & 0.870 & 0.879 \\
\hline
\end{tabular}

\section{Conclusion}

The pilot study undertaken is vital before conducting the main study on e-learning usage outcomes among university learners. The usability of the questionnaire as tested and the positive response rate confirmed the reliability of the larger investigation in future. Furthermore, the pilot study demonstrated that online survey was conducive for data collection. This paper highlights the importance of pilot study and contributes to the development of best practices in e-learning research. The positive response during the pilot study from postgraduates confirmed that the instruments are suitable for the main study and this was a crucial outcome. Finally, it was evident from this pilot study that in the e-learning context, TBP theory, IS Success Model and Attachment Theory could be an effective research framework in accessing e-learning usage and performance. This paper highlights the value of pilot study in term of improved research design and add to the body of knowledge of pilot study and e-learning context.

\section{References}

Ajzen, I., 1985. From intentions to actions: A theory of planned behavior. In: Kuhl J., Beckmann J. (eds) Action Control. SSSP Springer Series in Social Psychology. Berlin, Heidelberg: Springer. Available from https://doi.org/10.1007/978-3-642-69746-3_2.

Ajzen, I., 2011. The theory of planned behaviour: Reactions and reflections. Psychology \& Health, 26(9): 1113-1127.Available at: https://doi.org/10.1080/08870446.2011.613995.

Alharbi, S. and S. Drew, 2014. Using the technology acceptance model in understanding academics' behavioural intention to use learning management systems. International Journal of Advanced Computer Science and Applications, 5(1): 143-155.Available at: https://doi.org/10.14569/ijacsa.2014.050120.

Aparicio, M., F. Bacao and T. Oliveira, 2017. Grit in the path to e-learning success. Computers in Human Behavior, 66: 388-399.Available at: https://doi.org/10.1016/j.chb.2016.10.009

Arpaci, I., 2015. A comparative study of the effects of cultural differences on the adoption of mobile learning. British Journal of Educational Technology, 46(4): 699-712.Available at: https://doi.org/10.1111/bjet.12160.

Asatryan, V.S., L. Slevitch, R. Larzelere, C. Morosan and D.J. Kwun, 2013. Effects of psychological ownership on students' commitment and satisfaction. Journal of Hospitality \& Tourism Education, 25(4): 169-179.Available at: https://doi.org/10.1080/10963758.2013.850294.

Bowlby, J., 1960. Seperation anxiety: A critical review of the literature. Journal of Child Psychology and Psychiatry, 1(4): 251-269.Available at: 10.1111/j.1469-7610.1960.tbo1999.x.

Cooper, D.R. and P.S. Schindler, 2003. Business research methods. 8th Edn., Boston: McGraw-Hill Irwin.

Cortina, J.M., 1993. What is coefficient alpha? An examination of theory and applications. Journal of Applied Psychology, 78(1): 98104.Available at: https://doi.org/10.1037//0021-9010.78.1.98.

DeLone, W.H. and E.R. McLean, 1992. Information systems success: The quest for the dependent variable. Information Systems Research, 3(1): 60-95.Available at: https://doi.org/10.1287/isre.3.1.60.

Duckworth, A.L. and P.D. Quinn, 2009. Development and validation of the short grit scale (GRIT-S). Journal of Personality Assessment, 91(2): 166-174.Available at: https://doi.org/10.1080/00223890802634290.

Eldridge, S., G. Lancaster, M. Campbell, L. Thabane, S. Hopewell, C. Coleman and C. Bond, 2016. Defining feasibility and pilot studies in preparation for randomised controlled trials: Development of a conceptual framework. PloS one, 11(3): e0150205e0150205.Available at: https://doi.org/10.1371/journal.pone.0150205.

Fredrickson, J., 2015. Online learning and student engagement: Assessing the impact of a collaborative writing requirement. Academy of Educational Leadership Journal, 19(3): 127-140.

Hair, J.F., C. Ringle and M. Sarstedt, 2010. Partial least squares structural equation modeling: Rigorous applications, better results and higher acceptance. Long Range Planning, 46(1-2): 1-12.Available at: https://doi.org/10.1016/j.lrp.2013.01.001.

Hair, J.F., C.M. Ringle and M. Sarstedt, 2011. PLS-SEM: Indeed a silver bullet. Journal of Marketing Theory and Practice, 19(2): 139152.Available at: https://doi.org/10.2753/mtp1069-6679190202.

Hsieh, L.F., Y.C. Wu and J.J. Lu, 2016. What's the relationship between learning satisfaction and continuing learning intention? Procedia Social and Behavioral Sciences, 191: 2849-2854.

Lancaster, G.A., 2015. Pilot and feasibility studies come of age! Pilot and Feasibility Studies, 1(1): 1-4.Available at: https://doi.org/10.1186/2055-5784-1-1.

Lee, J. and A. Suh, 2015. How do virtual community members develop psychological ownership and what are the effects of psychological ownership in virtual communities? Computers in Human Behavior, 45: 382-391.Available at: https://doi.org/10.1016/j.chb.2014.12.002.

Lu, J., C.-S. Yu, C. Liu and J. Yao, 2009. Technology acceptance model for wireless internet. Internet Research, 13(3): $206-222$.

Mohammadyari, S. and H. Singh, 2015. Understanding the effect of e-learning on individual performance: The role of digital literacy. Computers \& Education, 82: 11-25.Available at: https://doi.org/10.1016/j.compedu.2014.10.025.

Moore, C.G., R.E. Carter, P.J. Nietert and P.W. Stewart, 2011. Recommendations for planning pilot studies in clinical and translational research. Clinical and Translational Science, 4(5): 332-337.Available at: https://doi.org/10.1111/j.1752-8062.2011.00347.x.

Mouakket, S. and A.M. Bettayeb, 2015. Investigating the factors influencing continunace usage intention of leaning management systems by university instructors: The blackboard system case. International Journal of Web Information Systems, 11(4): 491-509.Available at: https://doi.org/10.1108/ijwis-03-2015-0008.

Nurakun, K.Z., R. Ismailova and H. Dündar, 2018. Learning management system implementation: A case study in the Kyrgyz Republic. Interactive Learning Environments, 26(8): 1010-1022.Available at: https://doi.org/10.1080/10494820.2018.1427115.

Oh, J.-C. and S.-J. Yoon, 2014. Predicting the use of online information services based on a modified UTAUT model. Behaviour \& Information Technology, 33(7): 716-729.Available at: https://doi.org/10.1080/0144929x.2013.872187.

Oppenheim, A.N., 1992. Questionnaire design, interviewing and attitude measurement. 2nd Edn., London: Bloomsbury Publishing.

Oye, N.D., N. Iahad and N. Ab Rahim, 2014. The history of UTAUT model and its impact on ICT acceptance and usage by academicians. Education and Information Technologies, 19(1): 251-270.Available at: https://doi.org/10.1007/s10639-012-9189-9.

Pappas, C., 2015. The top E-learning statistics and facts for 2015 you nedd to know. Available from https://elearningindustry.com/elearning-statistics-and-facts-for-2015. 
Peña-Ayala, A., H. Sossa and I. Méndez, 2014. Activity theory as a framework for building adaptive e-learning systems: A case to provide empirical evidence. Computers in Human Behavior, 30: 131-145.Available at: https://doi.org/10.1016/j.chb.2013.07.057.

Read, W., N. Robertson and L. McQuilken, 2011. A novel romance: The technology acceptance model with emotional attachment. Australasian Marketing Journal (AMJ), 19(4): 223-229.

Sekaran, U. and B. Roger, 2016. Research methods for business: A skill-building approach. 6th Edn., Hoboken: John Wiley and Sons.

Teijlingen, E.V. and V. Hundley, 2002. The importance of pilot studies. Nursing Standard, 16(40): 33-36.Available at: http://dx.doi.org/10.7748/ns.16.40.33.s1.

Teo, T. and P. Van Schaik, 2012. Understanding the intention to use technology by preservice teachers: An empirical test of competing theoretical models. International Journal of Human-Computer Interaction, 28(3): 178-188.Available at: https://doi.org/10.1080/10447318.2011.581892.

$\mathrm{Wu}$, B. and C. Zhang, 2014. Empirical study on continuance intentions towards E-Learning 2.0 systems. Behaviour \& Information Technology, 33(10): 1027-1038.Available at: https://doi.org/10.1080/0144929x.2014.934291.

Wu, T., Y. Lu, X. Gong and S. Gupta, 2017. A study of active usage of mobile instant messaging application: An attachment theory perspective. Information Development, 33(2): 153-168.Available at: https://doi.org/10.1177/0266666916646814.

Yakubu, M.N. and S.I. Dasuki, 2018. Factors affecting the adoption of e-learning technologies among higher education students in Nigeria: A structural equation modelling approach. Information Development, 35(3): 492-502.

Yin, R., 1989. Case study research. Design and methods. 4th Edn., Newbury Park: Sage.

Zikmund, W.G., B.J. Babin, J.C. Carr and M. Griffin, 2012. Business research methods. 8th Edn., U.S: South-WesternCengage Learning. 